\title{
A Study of Language Learning Strategy Use among Indonesian EFL University Students
}

\author{
Agus Rianto \\ English Education Department, Faculty of Teacher Training and Education, \\ Universitas Borneo Tarakan, Tarakan City, 77123, Indonesia \\ Email: riant2@hotmail.com \\ DOI: 10.18326/rgt.v13i2.231-256
}

Submission Track:

Received: 03-08 -2020

Final Revision: 13-10-2020

Available Online: 01-12-2020

Copyright @ 2020 Agus Rianto

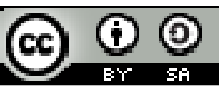

This work is licensed under a Creative Commons Attribution-ShareAlike 4.0 International License.

\begin{abstract}
This study investigated the use of language learning strategies among 329 Indonesian undergraduate students in their English as foreign language learning. The Strategy Inventory for Language Learning (SILL) Version 7.0 for ESL/EFL learners developed by Oxford was employed to measure the students' EFL learning strategies based on gender, study program, and English proficiency differences. A descriptive analysis and an independent $t$-test were used to analyze the collected data. The findings showed that the female, the social science, and the higher English proficiency students used overall language learning strategies more frequently in their EFL learning. Metacognitive was the strategy category most used by the students and compensation was the least used one. The memory, cognitive, metacognitive, affective, and social strategy categories were used at a high level and the compensation strategy category, at a moderate level. Although there were significant differences in the use of overall strategy and strategy categories between males and females and between social science and science students, no significant differences were found in use between students with lower and higher English proficiency. The findings had several practical implications in the process of EFL learning, especially in the higher education context.
\end{abstract}

Keywords: language learning strategy; English proficiency; gender; SILL; study programs 
Agus Rianto

\section{INTRODUCTION}

The use of appropriate language learning strategies is believed to be one of the factors that can help achieve the goal of foreign language learning. Studies have confirmed that language learning strategies help students become more effective in the classroom and encourage the development of more efficient mastery of the target language use (al-Qahtani, 2013; Oxford, 2016; Wong \& Nunan, 2011).

The present study adopted Oxford's (1990) Strategy Inventory for Language Learning (SILL) as its instrument to measure EFL learning strategies of Indonesian university students based on their gender, study program, and English proficiency differences. The main reason for choosing this inventory accounts for its high reliability and the fact that it is a widely employed instrument in investigating the use of language learning strategies for EFL students (Oxford and Burry-Stock, 1995). Within Oxford's (1990) framework, the six categories of language learning strategies are classified into two taxonomic sets, namely direct and indirect strategies. Direct language learning strategies, which include memory, cognitive, and compensation strategies, require mental processes to receive, maintain, store, and take words or other aspects of the target language. Indirect language learning strategies that consist of metacognitive, affective, and social strategies are more about learning organizations through activities that allow students to regulate thoughts and feelings. Oxford has recently reviewed her strategy categories and developed a model with four different strategy categories, namely cognitive, affective, sociocultural-interactive, and meta-strategies. Meta-strategies consist of metacognitive, meta-affective, and meta-sociocultural-interactive strategies (Griffith and Oxford, 2014; Oxford, 2016). In this study, language learning strategies were defined in line with the concepts put forward by Oxford-as processes and actions that were consciously used by language learners to help learn or use language more effectively.

Various studies on language learning strategies have aimed at identifying the strategies frequently used by language learners. In comparing the use of direct and indirect strategies on vocabulary learning of EFL Iranian high school students, Taghinezhad, Azizi, Shahmohammadi, Kashanifar, \& Azadikhah 
(2016) found that students at the upper secondary level tended to opt for more indirect than direct language learning strategies and teaching students about indirect learning strategies proved beneficial for students at the middle to the upper level. Teachers were advised to help students organize their ideas, negotiate their daily events and experiences, and discuss their feelings with each other while learning in class. Meanwhile, in a study conducted with preintermediate students in an Iranian university, Naeimi \& Foo (2015) found that students who used direct strategies outperformed those who opted for indirect strategies in vocabulary learning. The use of direct strategies at the preintermediate level led the students to higher achievement vocabulary storage in reading comprehension. Teachers were encouraged to implement direct language learning strategies in the early stages of vocabulary learning because it was practically effective. These studies have emphasized the importance of implementing appropriate language learning strategies in helping students achieve their foreign language learning goals.

Some researchers have reported students' preferences in using language learning strategies and factors influencing their strategy choices in their EFL learning. Overall, the most commonly adopted strategies were metacognitive, compensation, and cognitive. However, Chamot (2004) argued that different strategy preferences were influenced by different cultural contexts. Chinese and Singaporean students reported higher use of social strategies and lower use of affective strategies than European students. Yang (2007) found that compensation was the strategy most often used by Chinese students for its ability to provided learners with a great opportunity to guess meanings even with limited grammar and vocabulary knowledge. In addition, Shmais (2003) reported that memory strategies were most widely used by students who majored in English at a Palestinian university and compensation strategies were the least used strategy because it was linked to the culture and education system. It was mentioned that in Palestine students had limited opportunities to use functional practice strategies, especially in large classes because passing exams and answering questions directly related to the specified textbook represented the main focus. As a result, students were reluctant to use compensation strategies. A study by Lengkanawati (2004) revealed that the use of memory strategies that were not sensitive to EFL students was an indication 
that it was a cultural habit. For example, according to Australian students, remembering difficult words was an ineffective learning strategy while Indonesian students claimed to have a habit of learning to memorize. Besides cultural differences, several important factors that influenced the choice of language learning strategies were age, the nature of assignments, and course methodology (Suesca Torres \& Torres Pérez, 2017). These studies have identified that the cultural context and education system were the factors that influenced the choice of students' language learning strategies. Further studies need to explore other factors that might also influence the selection of students' language learning strategies including gender, study program, and level of language proficiency because findings from such studies can help create an effective process of foreign language learning.

\section{Gender and Use of Language Learning Strategies}

Various studies have examined the use of language learning strategies based on gender differences. The results of these studies have mixed conclusions; while some research results have shown differences in language learning strategy use between female and male students, other research studies have reported opposite findings. In a study involving Turkish students, Tezcan and Deneme (2015) found significant differences in the overall language learning strategies used by the students. The study found that female students resorted to more language learning strategies compared to their male counterparts. Similarly, in investigating language learning strategies (LLS) used by Saudi EFL students (66 males, 68 females), Alhaysony (2017) found that female students used more LLS than male students, although the difference was not significant. However, research by Hakan et al. (2015) found a significant difference only in the compensation strategies, which were more widely used by male students compared to their female counterparts. In addition, in a study of 56 pre-university students, Kiram et al. (2014) found that females used more strategies than males for all language learning strategies, except for compensation strategies, where these strategies were more dominant among males. However, further tests revealed that there were only significant differences in the use of cognitive and social strategies based on gender. 
On the other hand, other studies found no differences in the use of language learning strategies based on gender. In a study on Malaysian students, Kashefian-Naeeini and Maarof (2010) found no significant differences in all gender-based language learning strategies even though women were more likely to use memory, metacognitive and affective strategies than men. Nguyen and Godwyll (2010) also revealed no significant differences in the use of language learning strategies based on gender even though women have a higher tendency to use more language learning strategies. In addition, in a study on Turkish students, Kayaoğlu (2012) found that there were no significant differences in the use of overall language learning strategy among male and female science students, although significant differences were found in the use of individual language learning strategies.

These studies have revealed that the influence of gender has produced various findings in the use of LLS. However, research focusing on gender influence on the choice of LLS among Indonesian students remains limited. Such research is of key importance as it can help create an effective foreign language learning process. What makes this study different from previous research is the investigation of the level of LLS used by Indonesian students in EFL learning based on gender differences.

\section{Academic Programs and Use of Language Learning Strategies}

An academic program has been considered by researchers as one of the factors influencing students in the selection of language learning strategies. In a study examining the relationship between academic programs and the use of language learning strategies among Chinese students, Rao (2005) found that students from the social science program employed language learning strategies with a greater frequency than students from the science program on the overall and the individual strategies. Using the Strategy Inventory for Language Learning (SILL) developed by Oxford (1990), the study revealed that 5 strategy items related specifically to English learning were used more frequently by social science students, while 4 strategy items clearly related to logical analysis and associations were more often used by science students. In addition, in a study investigating strategies of learning English as a foreign language at the Faculty of Technical Sciences, University of Novi Sad, Šafranj 
(2013) found that university majors influenced the use of students' language learning strategies. The students from the industrial management major used the resourceful independent strategies more often than the students from the other two majors examined, electrical engineering and graphic and design engineering. Also, the industrial management students used the functional practice strategies significantly more often than the Electrical Engineering students, but not significantly more often than the graphic and design engineering students. In other studies, Chamot et al. (1987) and Oxford \& Nyikos (1989) reported that academic majors were shown to have a statistically significant effect on the choice of language learning strategies, with the students from humanities/social/education majors using independent strategies and functional practice (authentic language use) strategies more often than the students from other majors. In a previous study, Politzer \& McGroarty (1985) found that specification fields such as engineering/science vs. social science/humanities significantly influenced students on strategy choices in learning English as a second language, with engineering students tending to avoid strategies that were considered positive for getting communicative language proficiency. However, slightly contradictory results were found by $\mathrm{Gu}(2002)$ that despite differences in strategies in the arts and science majors, academic majors did not become strong background factors in influencing the use of language learning strategies.

Although there were inconsistent results, these studies in general revealed that there was a relationship between study programs and students' selection of language learning strategies. Students from humanities/social/education programs are more likely to use language learning strategies and choose independent and functional practice strategies than students from other programs. These results indicate that certain types of language learning strategies might be more appropriate for students from certain study programs. Further research needs to explore this issue because the use of appropriate language learning strategies is believed to have a positive effect on the achievement of language learning. Research that focuses on this issue is scarce, and for the context of learning English as a foreign language in Indonesia, this was the first research study conducted. 


\section{Language Proficiency and Use of Language Learning Strategies}

Language proficiency is believed to have a role in the selection of language learning strategies used by students. Various studies have specifically investigated the use of LLS among students with different levels of English proficiency. In general, English proficiency is measured among others through self-ratings, results of proficiency and achievement tests, and scores of English courses (Habók \& Magyar, 2018). In a recent study examining the use of LLS among Indonesian high school students with different English proficiency levels, Sartika, Santihastuti, and Wahjuningsih (2019) revealed that metacognitive was the strategy most often used by more efficient students, whereas cognitive was the strategy most often used by less efficient students. The study also showed that more efficient students used overall strategies more frequently than less efficient students. This was an indication that the more efficient students had the ability to plan clear goals, control, review, and evaluate their learning than their counterparts, who were more focused on the way they thought, memorized, summarized, and repeated learning. Another recent study by Abdul-Ghafour and Alrefaee (2019) identified the use of language learning strategies between higher and lower-achieving students in a Yemeni university. The study found that the strategies more often used by the high-achieving students were metacognitive, compensatory, and cognitive while those less frequently used by these students were affective, memory, and social. Meanwhile, the strategies more often used by low-achieving students were metacognitive and affective and those less frequently used by these students were cognitive, social, and memory. In a study identifying what language learning strategies were often used by EFL undergraduates at a state university in Thailand, Charoento (2016) revealed that students who had higher English language skills used the most metacognitive strategies, while those who had lower English language skill used the most social strategies. In addition, al-Qahtani (2013) who investigated the use of LLS among applied medical science undergraduates in Saudi Arabia found that high English achieving students mainly opted for cognitive strategies. A Study of Taiwanese EFL students revealed that English proficiency significantly influenced the use of language learning strategies, with high-level students using strategies more 
often than low-level students especially for cognitive, metacognitive, and social strategies (Rao, 2016). Furthermore, Magogwe and Oliver (2007) discovered that the basic difference in the use of language learning strategies between these students was that more successful students not only used certain strategies significantly more often, but they also chose the most adequate strategy depending on the goals their assignment.

It can be concluded from these studies that English proficiency plays a role in the selection of language learning strategies and that students with higher English proficiency used more language learning strategies than those with lower English proficiency. Preferences in the use of language learning strategies possessed by students with different English skills need to be further investigated in different contexts. Studies with such a focus are highly recommended to be carried out in Indonesia to complement the lack of empirical data and literature specifically related to the use of language learning strategies among students in a higher education context.

\section{Research Questions}

Although various studies have examined the use of language learning strategies among EFL students, the literature revealed very limited data on the use of language learning strategies among Indonesian university students. The main motivation of this study was to respond to the literature deficit mainly related to the use of LLS by Indonesian EFL students in the higher education context. Therefore, this study was carried out to investigate the following research questions:

1. Which group of Indonesian university students based on gender, study programs, and English proficiency used overall language learning strategies more frequently in their EFL learning?

2. Which strategy categories were the most and the least used by the students?

3. What were the levels of the students' language learning strategy use?

4. Were there significant differences in the use of language learning strategies based on gender, study programs, and English proficiency? 


\section{RESEARCH METHOD}

\section{Participants}

Respondents of this study were Indonesian native speakers who learned English as a foreign language at the Universitas Borneo Tarakan, Indonesia. Of the 340 students who filled out the questionnaire, 329 were taken as the final respondents after 11 were rejected because there were values missing in their responses. They consisted of 147 males and 182 females. The students were enrolled in 16 study programs and for the purpose of this research they were categorized into two groups-the social science students (53\%) and the science students (47\%). In addition, measured through scores obtained in an English test, a total of 246 respondents were categorized into lower English skill students and 83 were into higher English skill students.

\section{Instruments}

The Strategy Inventory for Language Learning (SILL) for ESL/EFL learners developed by Oxford (1990) was used to assess the respondents' language learning strategy use. The questionnaire was organized into six strategy groups (Parts A-F) categorized according to Oxford's original identification and classification system. Part A (memory strategies) consists of strategies used to store, remember, and retrieve information. These strategies reflect very simple principles, such as organizing things in sequence, making associations, and reviewing them. Consisting of 9 items, these strategies are divided into four sets: creating mental links, applying images and sounds, reviewing well, and employing actions. Part B (cognitive strategies) consists of mental processes in learning a new language ranging from repetition, expression analysis to summation, with all its variations. Cognitive strategies are united by a general function of manipulation or transformation of the target language by students. This strategy category is the largest strategy group in SILL, which includes 14 items related to practice and in-depth processing that students use to analyze new information and monitor understanding. Part C (compensation strategies) consists of strategies that allow students to use a new language for understanding or production even though there are limitations in knowledge. These strategies have 6 items, which include guessing the meaning from context and using gestures or synonyms to convey meaning when language is 
limited. Compensation strategies are grouped into two sets: smart guessing in listening and reading, and overcoming limitations in speaking and writing. Part $\mathrm{D}$ (metacognitive strategies) consists of actions that go beyond pure cognitive devices and which provide ways for students to coordinate their own learning processes. These strategies consist of 9 items that can be grouped into three sets: centralizing learning, organizing and planning learning, and evaluating learning. Part E (affective strategies) consists of affective factors such as emotions, attitudes, motivations, and values. These strategies help students gain control over these factors. Consisting of 6 items, these strategies are grouped into three main sets: anxiety reduction, self-impulse, and gifts. Part F (social strategies) is connected to the communication process that occurs between and among people. These strategies consist of 6 items including asking questions, collaborating with peers, and becoming culturally aware. High reliability coefficient for SILL (from 0.85 to 0.98), as reported by Oxford and Burry-Stock (1995), has made it the most widely used instrument in investigating the use of language learning strategies for EFL students was the main reason why it was used in this study.

\section{Procedure}

To assess the use of the respondents' language learning strategies, SILLwhich included gender and study program information-was given to the students outside of their lecture hours. The students were informed that the personal information they provided was solely for research purposes and therefore confidentiality was fully guarded. They were also informed that they would find statements about learning English and to read each statement carefully. They were asked to answer in terms of how well the statements described them, not how they should be, or what other people were doing. There were no right or wrong answers to the statements. Respondents were instructed to circle the numbers $1,2,3,4$, or 5 .

To measure their use of language learning strategies, the respondents were asked to circle the numbers $1,2,3,4$, or 5 which indicated how true each statement was to them. The five-point Likert scale is developed by Oxford. Number l (Never or almost never true of me) means that the statement is very rarely true to respondents. Number 2 (Usually not true of me) means that the 
statement is true less than half the time. Number 3 (Somewhat true of me) means that statement is true half the time. Number 4 (Usually true of me) means that statement is true more than half the time. Number 5 (Always or almost always true of me) means that the statement is always true to respondents. To find out levels of use of the language learning strategies, this study employed a scale of strategy usage developed by Oxford (1990) which consists of three levels: high usage (mean scores of 3.5-5.0), moderate usage (mean scores of 2.5-3.4), and low usage (mean scores of 1.0-2.4). To find out the gender and academic programs of the respondents, this study added two items in the SILL, each asking about the study program and the gender. To determine the respondents' English proficiency, this study used scores of a paper-based English test consisting of listening comprehension, structure and written expression, and reading comprehension. This test was administered by the university's language center. Based on the test scores obtained, the students were grouped into two categories: lower English skills (those with the English test scores of less than 460) and higher English skills (those with the English test scores of 460 and above). This categorization of English proficiency was in accordance with what was determined by the university.

\section{Data Analysis}

This research used descriptive and quantitative methods. The Statistical Package for Social Sciences (SPSS, version 14.0) for Microsoft Windows was used to help analyze the data collected. The descriptive analysis was carried out to answer the first, second, and third research questions. In addressing the first research question, the mean scores of the overall strategy use were compared. To answer the second research question, the mean scores of each strategy category were compared and ranked. To address the third research question, the mean scores of each strategy category were classified using the Oxford's scale of strategy usage. Finally, an independent t-test with a p-value of 5\% (0.05) was performed to address the fourth research question.

\section{FINDINGS AND DISCUSSION}

This study sought to examine language learning strategies used by Indonesian university students in their EFL learning based on gender, study 
programs, and English proficiency. Specifically, the examination was focused on the use of the overall strategy, the use of the strategy categories, levels of the strategy use, and differences in the strategy use based on gender, study programs, and English proficiency.

\section{Strategy Use by Gender}

The analysis of language learning strategies use by gender was focused on the overall strategy use, the strategy category use, levels of the strategy use, and differences in the strategy use between the male and the female students. Results of the descriptive analysis on language learning strategy use by gender are reported in Table 1.

Table 1. Descriptive Analysis of Language Learning Strategy Use by Gender

\begin{tabular}{|c|c|c|c|c|c|c|}
\hline \multicolumn{2}{|c|}{ Strategy Category } & Gender & Mean & S.D & $\begin{array}{l}\text { Strategy } \\
\text { Use Level }\end{array}$ & $\begin{array}{l}\text { Strategy } \\
\text { Use Rank }\end{array}$ \\
\hline \multirow{6}{*}{ Direct } & \multirow{2}{*}{ Memory } & Male & 3.66 & .46 & High & 4 \\
\hline & & Female & 3.82 & .44 & High & 4 \\
\hline & \multirow[t]{2}{*}{ Cognitive } & Male & 3.55 & .53 & High & 5 \\
\hline & & Female & 3.67 & .47 & High & 5 \\
\hline & \multirow[t]{2}{*}{ Compensation } & Male & 3.23 & .61 & Moderate & 6 \\
\hline & & Female & 3.28 & .62 & Moderate & 6 \\
\hline \multirow{6}{*}{ Indirect } & \multirow[t]{2}{*}{ Metacognitive } & Male & 3.95 & .57 & High & 1 \\
\hline & & Female & 4.09 & .48 & High & 1 \\
\hline & \multirow[t]{2}{*}{ Affective } & Male & 3.70 & .61 & High & 3 \\
\hline & & Female & 3.89 & .56 & High & 3 \\
\hline & \multirow[t]{2}{*}{ Social } & Male & 3.90 & .53 & High & 2 \\
\hline & & Female & 4.03 & .53 & High & 2 \\
\hline \multirow{2}{*}{\multicolumn{2}{|c|}{ Overall Strategy Use }} & Male & 3.66 & .41 & High & \\
\hline & & Female & 3.80 & .36 & High & \\
\hline
\end{tabular}

Table 2. Results of t-Test for Strategy Use by Gender

\begin{tabular}{lllll}
\hline \multicolumn{2}{l}{ Strategy Category } & $\mathrm{t}$ & $\mathrm{df}$ & Sig. (2-tailed) \\
\hline \multirow{4}{*}{ Direct } & Memory & -3.15 & 327 & $.00^{*}$ \\
& Cognitive & -2.29 & 327 & $.02^{*}$ \\
\multirow{4}{*}{ Indirect } & Compensation & -.81 & 327 & .42 \\
\multirow{2}{*}{ Overall Strategy Use } & Metacognitive & -2.40 & 285 & $.02^{*}$ \\
& Affective & -2.40 & 327 & $.00^{*}$ \\
& Social & -2.35 & 327 & $.02^{*}$ \\
\end{tabular}

* Differences were significant at the 0.05 level (2-tailed) 
The female students used more language learning strategies than the male students in their EFL learning as indicated by the mean scores of the overall strategy use (male $=3.66$; female $=3.80$ ). Metacognitive, social, and affective were the strategy categories more frequently used by both the male and the female students, while memory, cognitive, and compensation were the strategy categories less frequently used by these two groups of students. Both the male and the female students used, at a high level, the memory, cognitive, metacognitive, affective, and social strategy categories and, at a moderate level, the compensation strategy category. The levels of strategy use were determined according to the Oxford's scales: high usage (mean scores of 3.5-5.0), moderate usage (mean scores of 2.5-3.4), and low usage (mean scores of 1.0-2.4).

The female students had greater mean scores than the male students for the overall strategy use and the strategy category use. As reported in Table 2, results of the independent t-test with a p-value of 0.05 showed that significant differences were found between the male and the female students for the overall strategy use and for five of the six strategy category use (memory, cognitive, metacognitive, affective, and social). However, there was no significant difference between the male and the female students for the use of the compensation strategy category. These findings were compatible with those of the previous studies on language learning strategies, which indicated that female students used more language learning strategies than male students (Alhaysony, 2017; Tezcan \& Deneme; 2015). Overall, the female students in this study tended to be more concerned with the learning process and actions to help them learn or use English more effectively. An explanation of this finding could be for most Indonesian female learners, failure in English learning seems to be something very embarrassing and they have a high expectation that they must be successful. The results of this study also revealed that metacognitive, social, and affective were the strategy categories that were more often used by both the male and the female students, with high-level usage. Oxford (1990) classifies these three strategy categories as indirect strategies, meaning that although they are not directly involved in language learning, they can support direct learning strategies and manipulate language learning. This finding indicated that in learning English as a foreign language, 
the male and the female students preferred strategies that managed learning through activities that facilitated them in organizing their thoughts and feelings such as centralizing learning, organizing and planning learning, and evaluating learning (metacognitive strategies); anxiety reduction, self-impulse, and gifts (affective strategies); asking questions, collaborating with peers, and becoming culturally aware (social strategies). Another interesting finding in this study was that the males and the females used the least the compensation strategy category, meaning that these two groups of students did not like learning activities that allowed them to use new languages for understanding or production such as guessing the meaning from context and using gestures or synonyms to convey ideas. This was likely due to the limited knowledge they had in English such as in listening, reading, speaking and writing.

\section{Strategy Use by Study Programs}

The analysis of language learning strategy use by study programs was focused on the use of the overall strategy, the use of the strategy categories, levels of the strategy use, and differences in the strategy use between the social science and the science students. Results of the descriptive analysis on language learning strategy use by study programs are reported in Table 3.

Table 3. Descriptive Analysis of Strategy Use by Study Programs

\begin{tabular}{|c|c|c|c|c|c|c|}
\hline \multicolumn{2}{|c|}{ Strategy Category } & $\begin{array}{l}\text { Study } \\
\text { Program }\end{array}$ & Mean & S.D & $\begin{array}{l}\text { Strategy } \\
\text { Use Level }\end{array}$ & $\begin{array}{l}\text { Strategy } \\
\text { Use Rank }\end{array}$ \\
\hline \multirow{6}{*}{ Direct } & \multirow{2}{*}{ Memory } & Social Science & 3.82 & .43 & High & 4 \\
\hline & & Science & 3.67 & .48 & High & 4 \\
\hline & \multirow{2}{*}{ Cognitive } & Social Science & 3.70 & .46 & High & 5 \\
\hline & & Science & 3.52 & .54 & High & 5 \\
\hline & \multirow[b]{2}{*}{ Compensation } & Social Science & 3.25 & .63 & Moderate & 6 \\
\hline & & Science & 3.27 & .61 & Moderate & 6 \\
\hline \multirow{6}{*}{ Indirect } & \multirow{2}{*}{ Metacognitive } & Social Science & 4.12 & .47 & High & 1 \\
\hline & & Science & 3.92 & .56 & High & 1 \\
\hline & \multirow{2}{*}{ Affective } & Social Science & 3.87 & .57 & High & 3 \\
\hline & & Science & 3.73 & .60 & High & 3 \\
\hline & \multirow[b]{2}{*}{ Social } & Social Science & 4.03 & .52 & High & 2 \\
\hline & & Science & 3.91 & .54 & High & 2 \\
\hline \multirow{2}{*}{\multicolumn{2}{|c|}{ Overall Strategy Use }} & Social Science & 3.80 & .37 & High & \\
\hline & & Science & 3.67 & .39 & High & \\
\hline
\end{tabular}


The social science students had higher mean scores than the science students for the use of the overall strategy and for the use of the memory, cognitive, metacognitive, social, and affective strategy categories. Overall, the students from the social science programs used more language learning strategies than the students from the science programs in their EFL learning as indicated by the mean scores of the overall strategy use (social science $=3.80$; science $=3.67$ ). Metacognitive, social, and affective were the strategy categories used more frequently by both the social science and the science students, while memory, cognitive, and compensation were the strategy categories used less frequently by these two groups of students, although higher mean scores were obtained by the social science students. The students from both the social science and the science programs used the memory, cognitive, metacognitive, affective, and social strategy categories at a high level and the compensation strategy category at a moderate level. As reported in Table 4, results of the independent $\mathrm{t}$-test with a p-value of 0.05 showed that significant differences were found between the social science students and the science students for the use of the overall strategy and for the use of memory, cognitive, metacognitive, and affective strategy categories. No significant differences were found for the use of compensation and social strategy categories.

Table 4. Results of t-Test of Strategy Use by Study Programs

\begin{tabular}{lllll}
\hline \multicolumn{2}{l}{ Strategy Category } & $\mathrm{t}$ & $\mathrm{Df}$ & Sig. (2-tailed) \\
\hline \multirow{4}{*}{ Direct } & Memory & 3.20 & 327 & $.00^{*}$ \\
& Cognitive & 3.21 & 327 & $.00^{*}$ \\
\multirow{4}{*}{ Indirect } & Compensation & -.34 & 327 & .74 \\
& Metacognitive & 3.33 & 300 & $.00^{*}$ \\
\multirow{2}{*}{ Overall Strategy Use } & 2.06 & 327 & $.04^{*}$ \\
& Affective & 2.01 & 327 & .05 \\
\hline
\end{tabular}

*Differences were significant at the 0.05 level (2-tailed)

This finding is in accordance with what was found by Rao (2005) - that the students from social science programs employed more language learning strategies than the students from science programs. Further analysis in this study showed that significant differences were found in the use of the cognitive, 
metacognitive, and affective strategy categories between students from the two programs. These results indicated that compared to their counterparts from science programs the students from the social science programs were more involved in learning English activities aiming to store, remember, and retrieve information and in language learning activities that involved practice and indepth processing to analyze new information and monitor understanding. In addition, the students from social science programs tended to choose learning strategies that provided ways for them to coordinate their own learning processes and that involved affective factors such as emotions, attitudes, motivations, and values.

This is also consistent with the findings found by Chamot et al. (1987) and Oxford \& Nyikos (1989) that the students from humanities/social/education majors opted for independent strategies and functional practice (authentic language use) strategies more often than the students from other majors. The independent strategies included the independent use of foreign language materials to memorize words and sentences such as lists of related words, fabricating sentences and exercises, using mnemonics, complicated sentences, using tape recorders and independent use of certain metacognitive actions such as planning, self-testing or self-gift. These strategies are the same as the items $18,19,24,25,26,27,28$ and 29 in the SILL. The functional practice strategies required language practice in a natural environment outside the classroom such as watching foreign language films, finding native speakers for conversation, imitating native speakers, starting a foreign language conversation, and reading authentic material in a new language. These strategies are similar to the items 10,11, 15, 30, 31, 32, 35, 37 and 38 in the SILL.

The difference in the use of strategies between the two groups of students seems to be caused by the preferences of students' learning methods. Students who enter the learning environment in higher education are generally aware of their preferences about how to be involved in the learning process. Usually, the development of such preferences specifically comes from the learning approaches they adopt in everyday learning. Social science students are more closely related to language learning than science students. This is evidenced by the findings in Rao's (2005) study about 5 strategy items related specifically to 
English learning being used more frequently by social science students compared to science students, while 4 strategy items more often used by science students were clearly related to logical analysis and associations.

The application of curriculum in the Indonesian education system seems to be another reason of differences in the use of language learning strategies between the social science and the science students. In general, social science students in Indonesia are burdened with a relatively smaller number of academic jobs than science students. This allows social science students to use more time to learn English. In contrast, aside from the nature of the disciplines, science students seem to have more homework and experiments to complete their main studies. Such contrast could make a big difference in the use of language learning strategies. This explanation is in accordance with Rao's (2005) qualitative findings that social science students often used timeconsuming strategies such as summarizing new English material, previewing English lessons and reviewing English lessons more often than science students.

\section{Strategy Use by English Proficiency}

The analysis of language learning strategy use by English proficiency was focused on the use of the overall strategy, the use of strategy categories, levels of the strategy use, and differences in the strategy use between the students with lower English skills and the students with higher English skills. Results of the descriptive analysis on language learning strategy use by English proficiency are reported in Table 5.

The mean score of the overall language learning strategy use obtained by the students with higher English skills (3.76) was slightly higher than that of the students with lower English skills (3.73), indicating that the higher English skill students used the overall language learning strategies slightly more often than the lower English skill students in their EFL learning. For the students with higher English skills, the strategy categories more frequently used were social (4.02), metacognitive (3.97), and affective (3.85), while the strategy categories less frequently used were compensation (3.29), cognitive (3.62), and memory (3.82). For the students with lower English skills, the strategy categories more frequently used were metacognitive (4.04), social (3.96), and affective (3.79), 
while the strategy categories less frequently used were compensation (3.25), cognitive (3.62), and memory (3.73). Both the students with higher and lower English skills used, at a high level, the memory, cognitive, metacognitive, affective, and social strategy categories and, at a moderate level, the compensation strategy category.

Table 5. Descriptive Analysis of Strategy Use by English Proficiency

\begin{tabular}{|c|c|c|c|c|c|c|}
\hline \multicolumn{2}{|c|}{ Strategy Category } & $\begin{array}{l}\text { English } \\
\text { Proficiency }\end{array}$ & Mean & S.D & $\begin{array}{l}\text { Strategy } \\
\text { Use Level }\end{array}$ & $\begin{array}{l}\text { Strategy } \\
\text { Use Rank }\end{array}$ \\
\hline \multirow{6}{*}{ Direct } & \multirow[t]{2}{*}{ Memory } & Lower Skills & 3.73 & .46 & High & 4 \\
\hline & & Higher Skills & 3.82 & .44 & High & 4 \\
\hline & \multirow{2}{*}{ Cognitive } & Lower Skills & 3.62 & .52 & High & 5 \\
\hline & & Higher Skills & 3.62 & .45 & High & 5 \\
\hline & \multirow[t]{2}{*}{ Compensation } & Lower Skills & 3.25 & .62 & Medium & 6 \\
\hline & & Higher Skills & 3.29 & .58 & Medium & 6 \\
\hline \multirow{6}{*}{ Indirect } & \multirow[t]{2}{*}{ Metacognitive } & Lower Skills & 4.04 & .52 & High & 1 \\
\hline & & Higher Skills & 3.97 & .55 & High & 2 \\
\hline & \multirow[t]{2}{*}{ Affective } & Lower Skills & 3.79 & .60 & High & 3 \\
\hline & & Higher Skills & 3.85 & .56 & High & 3 \\
\hline & \multirow[t]{2}{*}{ Social } & Lower Skills & 3.96 & .53 & High & 2 \\
\hline & & Higher Skills & 4.02 & .53 & High & 1 \\
\hline \multirow{2}{*}{\multicolumn{2}{|c|}{ Overall Strategy Use }} & Lower Skills & 3.73 & .40 & High & \\
\hline & & Higher Skills & 3.76 & .36 & High & \\
\hline
\end{tabular}

Table 6. Results of t-Test of Strategy Use by English Proficiency

\begin{tabular}{lllll}
\hline \multicolumn{2}{l}{ Strategy Category } & $\mathrm{t}$ & $\mathrm{Df}$ & Sig. (2-tailed) \\
\hline \multirow{2}{*}{ Direct } & Memory & -1.67 & 327 & .10 \\
& Cognitive & -.06 & 327 & .95 \\
& Compensation & -.56 & 327 & .57 \\
& & & \\
\multirow{2}{*}{ Indirect } & Metacognitive & 1.11 & 327 & .27 \\
& Affective & -.85 & 327 & .40 \\
\multirow{2}{*}{ Overall Strategy Use } & -.92 & 327 & .36 \\
\hline
\end{tabular}

The students with higher English skills obtained greater mean scores for the memory, compensation, affective, and social strategy categories than the students with lower English skills. For the metacognitive strategy category, both groups of students got the same mean score, while for the cognitive strategy category the students with lower English skills obtained higher mean 
scores than their counterparts with higher English skills. However, as reported in Table 6, the results of the independent t-test with a p-value of 0.05 showed no significant differences between the two groups of students in the use of the six strategy categories and in the use of the overall strategies.

In general, this finding is not different from the results of the studies carried out previously (Oxford \& Burry-stock, 1995; Sartika, Santihastuti, and Wahjuningsih, 2019; Oxford, 1993; Yu, 2003), which indicated that students with higher language skills used more language learning strategies than those with lower language skills. However, the results of further analysis in this study found no significant differences in the use of all the strategy categories. This finding indicated that both the higher and the lower English skill students had the ability to plan clear goals, control, review, and evaluate their English learning as well as to focus on the way they thought, memorized, summarized, and repeated learning.

In addition, this study revealed that the students with higher English skills used the most the social strategy category, while the students with lower English skills used the most the metacognitive strategy category. This finding indicated that the students with higher English skills tended to prefer English learning activities that were connected to the communication processes such as asking questions, collaborating with peers, and becoming culturally aware. Meanwhile, the students with lower English skills tended to prefer English learning techniques that organized, focused, and evaluated their own learning. A more interesting finding in this study was that these two groups of students most rarely used the compensation strategy category, meaning that both the students with higher and lower English skills tended to dislike learning activities that allowed them to use new languages for understanding or production such as guessing or using movements even though to overcome the deficiencies and gaps in their current language knowledge.

\section{CONCLUSION}

This study examined the use of language learning strategies among Indonesian university students in their EFL learning based on gender, study programs, and English proficiency. As far as gender was concerned, the female 
students used more language learning strategies than the male students in their EFL learning. Metacognitive was the strategy category the most used by both the male and the female students, while compensation was the strategy category the least used by these two groups of students. Both the male and the female students used, at a high level, the memory, cognitive, metacognitive, affective, and social strategy categories and in moderate level the compensation strategy category. Significant differences were found between the male and the female students for the use of the overall strategy and for the use of the memory, cognitive, metacognitive, affective, and social strategy categories. No significant difference was found between the male and the female students for the use of compensation strategy category.

With regard to study programs, the social science students used more language learning strategies than the science students in their EFL learning. Metacognitive was the strategy category the most used by both the social science and the science students, while compensation was the strategy category the least used by these two groups of students. The students from both the social science and the science programs used, at high level, the memory, cognitive, metacognitive, affective, and social strategy categories and in moderate level the compensation strategy category. Significant differences were found between the social science students and the science students for the use of the overall strategy and for the use of the memory, cognitive, metacognitive, and affective strategy categories. No significant differences were found for the use of the compensation and social strategy categories.

In relation to English proficiency, the students with higher English proficiency used the overall language learning strategies slightly more often than the students with lower English proficiency in their EFL learning. For the higher English skill students, the strategy category most frequently used was social and the least frequently used was compensation. For the lower English skill students, the strategy category most frequently used was metacognitive and the least frequently used was compensation. Both the students with higher and lower English skills used in high level the memory, cognitive, metacognitive, affective, and social strategy categories and in moderate level the compensation strategy category. No significant differences were found 
between the two groups of students in the use of the six strategy categories and in the use of the overall strategies.

This study has several practical implications in the process of learning foreign languages in the classroom, especially at the higher education level. The existence of preferences in the use of language learning strategies pushes to the fore the need to give students further opportunities to practice a variety of strategies that suit different teaching tasks and activities. Students from science study programs may require more explicit instructions and practices in memory strategies and compensation strategies such as using a mnemonic tool to learn new vocabulary and guess meaning from context. While students of social science may need more practice in using language learning strategies related to logical analysis and associations such as finding meaning by dividing words into sections and connecting new material to what is already known.

Another implication is directly related to students, instructors, and developers of language learning syllabi. Students need to increase their awareness about the functions and use of the language learning strategy so that they are encouraged to choose and use strategies that are more appropriate at various stages of learning their target language. More importantly, awareness must also be built by language teachers as they need to recognize the significant role of using various strategies and other important factors to help their students in the language learning process. Awareness like this will help language teachers respect individual differences among language learners and thus can lead them towards applying learner-centered classes. For designers of syllabi and material developers, they must be aware of the importance of incorporating learning strategies into syllabi, textbooks, assignments and activities that not only require the development of learning strategies but also provide opportunities to use these strategies. Finally, as this study's finding showed variations in the use of strategies by students, a further explanation of this variation can be facilitated by further studies that focus on the influence of other individual variables on the strategy use such as motivation, attitudes, personality types, and learning styles. 
Agus Rianto

\section{Acknowledgements}

This study was supported by the Universitas Borneo Tarakan Grant.[rgt]

\section{REFERENCES}

Abdul-Ghafour, M. \& Alrefaee.Y. (2019). The Relationship between language learning strategies and achievement among EFL University Students. ALR Journal 3(3), 64-83.

Alhaysony, M. (2017). Language learning strategies use by Saudi EFL students: the effect of duration of English language study and gender. Theory and Practice in Language Studies 7(1), 18-28.

Al-Qahtani, M. F. (2013). Relationship between English language, learning strategies, attitudes, motivation, and students' academic achievement. Education in Medical. Journal. 5(3), 19-29.

Chamot, A., O’Malley, J., Kupper, L., \& Impink-Hernandez, M. (1987). Study of learning strategies in foreign language instruction: First year report. Rosslyn, Va.: Interstate Research Associates.

Charoento, M. (2016). Individual learner differences and language learning strategies. Contemporary Educational Researches Journal, 7(2), 57-72.

Cohen. A. D. (1998). Strategies in learning and using a second language. London: Longman.

Davut, N. (2019). Language learning strategies: A comparative study of young and adolescent Cambodian learners. International Journal of Language and Literary Studies, 1(2), 34-45.

Dawadi, S. (2017). Language learning strategies profiles of EFL learners in Nepal. European Journal of Educational and Social Sciences, 2 (2), 42 - 55.

Goh, C.C.M. \& Foong, K.P. (1997). Chinese ESL students' learning strategies: A look at frequency, proficiency, and gender. Hong Kong Journal of Applied Linguistics, 2(1), 39-53.

Griffith, C., and Oxford, R. (2014). The twenty-first century landscape of language learning strategies: introduction to this special issue. System, 43, 1-10. doi: 10.1016/j.system.2013.12.009

$\mathrm{Gu}, \mathrm{Y}$. (2002). Gender, academic major, and vocabulary learning strategies of Chinese EFL learners. RELC Journal, 33, 35-54. 
Habók A and Magyar A (2018). The effect of language learning strategies on proficiency, attitudes and school achievement. Frontiers in Psychology, 8, 1-8 doi: 10.3389/fpsyg.2017.02358

Halbach, A., (2000). Finding out about students' learning strategies by looking at their diaries: a case study. System, 28(1), 85-96.

Hismanoglu, M. (2000). Language learning strategies in foreign language learning and teaching. The Internet TESL Journal, 6(8), 1-6.

Ho, A. P., Ng, L. L. (2016). Gender-based differences in language learning strategies among undergraduates in a Malaysian public university. Issues in Language Studies, 5(2). 1-17. https://doi.org/10.33736/ils.1631.2016

Kashefian-Naeeini, S., Maarof, N. (2010). Language learning strategies used by ESL university students. International Journal of Learning,17(8), 47-61.

Kayaoğlu, M. N. (2012). Gender-based differences in language learning strategies of science students. Journal of Turkish Science Education, 9(2), 12-24.

Kiram, J. J., Sulaiman, J., Swanto, S., Din, W. A. (2014). The relationship between English language learning strategies and gender among preuniversity students: An overview of UMS. In W. Z. Wan Zin, S. C. DzulKifli,F.A. Razak \& A. Ishak (Eds.). AIP Publishing. doi: 10.1063/1.4882532

Lengkanawati, N.S. (2004). How learners from different cultural backgrounds learn a foreign language. Asian EFL Journal, 6(1), 1-8.

Liu, D. (2004). EFL proficiency, gender and language learning strategy use among a group of Chinese technological institute English majors. ARECLS-E Journals, 1,20-28.

Magogwe, J. M., Oliver, R. (2007). The relationship between language learning strategies, proficiency, age, and self-efficacy beliefs: a study of language learners in Botswana. System, 35, 338-352. doi: 10.1016/j.system.2007. 01.003

Naeimi, M. \& Chow Voon Foo, T. (2015). Vocabulary acquisition through direct and indirect learning strategies. English Language Teaching, 8(10), 140-150.

Nguyen, N., Godwyll, F. (2010). Factors influencing language-learning strategy use of English learners in an ESL Context. Mid-Western Educational Researcher, 23(4), 7-13.

Oxford, R. L. (1990). Language strategies: What every teacher should know. Newbury House Publishers. 
Agus Rianto

Oxford, R. L. (1993). Instructional implication of gender differences in language learning styles and strategies. Applied Language Learning, 4, 65-94.

Oxford, R. L. (2016). Teaching and Researching Language Learning Strategies: SelfRegulation in Context. New York, NY: Routledge.

Oxford, R. L., \& Burry-Stock, J. A. (1995). Assessing language learning strategies worldwide with the ESL/EFL version of the strategy inventory for language learning (SILL). System, 23(1), 1-23.

Oxford, R. L., \& Nyikos, M. (1989). Variables affecting choice of language learning strategies by university students. Modern Language Journal, 73, 291-300.

Oxford, R. L., Ehrman, M. E., \& Nyikos, M. (1988). Vive la difference? Reflections on sex differences in use of language learning strategies. Foreign Language Annals, 24, 321-329.

Oxford, R.L, Cho, Y., Leung, S., \& Kim, H.J. (2004). Effect of the presence and difficulty of task on strategy use: An exploratory study. IRAL, International Review of Applied Linguistics in Language Teaching, 42(1), 1-47.

Panggabean, C.I.T., \& Kesuma, I. (2017). Language learning strategies of high proficiency students in their oral presentation at English language education of PGRI Ronggolawe University Tuban. OKARA: Jurnal Bahasa dan Sastra, 11(2), 205-214.

Politzer, R., \& McGroarty, M. (1985). An exploratory study of learning behaviors and their relationship to gains in linguistic and communicative competence. TESOL Quarterly, 19, 103-124.

Rachmawati, Y. (2013). Language learning strategies used by learners in learning speaking. Journal of English and Education, 1(2),124-131.

Rao, Z. (2005). Gender, academic major, and chinese students' use of language learning strategies: Social and educational perspectives. The Journal of Asia TEFL, 2, 115-138.

Šafranj, J. (2013). Strategies of learning English as a foreign language at Faculty of Technical Sciences. Procedia - Social and Behavioral Sciences, 93, 775 - 782

Sartika, D. H. M., Santihastuti, A., Wahjuningsih, E. (2019). The learning strategies used by EFL students in learning English. IJEE (Indonesian Journal of English Education), 6(1), 10-20.

Shmais, W. A. (2003). Language learning strategy use in Palestine. TESL-EJ, 7(2), 3-21. 
Suesca Torres, F., \& Torres Pérez, A. (2017). Analysis of language learning strategies used by two groups of students of differing age range. Enletawa Journal, 9(2), 55-72.

Sumarni, S., \& Rachmawaty, N. (2019). Gender differences in language learning strategies. Ethical Lingua: Journal of Language Teaching and Literature, 6(1), 13-22.

Taghinezhad, A., Azizi, M., Shahmohammadi, S., Kashanifar, F.S., Azadikhah, M. (2016), Comparing the Effects of Direct and Indirect Learning Strategies on Iranian EFL Learners' Vocabulary Learning, Journal of Applied Linguistics and Language Research, 3(1), 133-143

Tanjung, F.Z. (2018). Language learning strategies in English as a foreign language classroom in Indonesian higher education context. LLTJournal (21), 50-68.

Tezcan, S., Deneme, S. (2015). A study on language learning strategy use of young Turkish learners. Journal of Language Teaching and Research, 7(1), $42-48$. doi: http://dx.doi.org/10.17507/jltr.0701.05

Wong, L. L. C., and Nunan, D. (2011). The learning styles and strategies of effective language learners. System 39, 144-163.

Wulandari, B. A. (2018). An evaluation of language learning strategies used by english students. IJEE (Indonesian Journal of English Education), 5(1), 16-25.

Yang, M. N. (2007). Language learning strategies for junior college students in Taiwan: Investigating ethnicity and proficiency. Asian EFL Journal, 9(2), 3557.

Yu, L. (2003). Learning strategies and their relationship to listening comprehension-A report on Non-English majors in a medical university in China. Teaching English in China, 26(4), 3-11. 
This page is intentionally left blank 